\title{
Transforming the social-ecological systems framework into a knowledge exchange and deliberation tool for comanagement
}

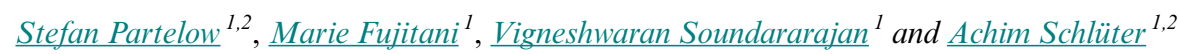

\begin{abstract}
The social-ecological system framework (SESF) can be useful for applied research and management practice beyond its traditional academic applications. In this article we transform the SESF into an image-based practical tool to facilitate knowledge exchange and deliberation processes within community-based natural resource comanagement settings. We develop a transdisciplinary methodology to transform the SESF into simple and context relevant images that are understandable by nonspecialists, yet the imagebased framework still conveys its core tenets of systems thinking, a checklist for system complexity and conceptualizing social-ecological interactions. We then demonstrate a mixed-method approach for testing the usefulness of the image-based framework for enhancing communication, knowledge exchange, and deliberation processes. We show how the academic uses of the SESF, its core tenets, can serve the same purpose for nonacademic actors. When transformed, the image-based SESF has potential to be a tool that can enhance communication and knowledge exchange between actors in governance settings. We demonstrate our methodology with small-scale fishers involved with comanagement in the Gulf of Nicoya, Costa Rica. In the example, we show how scientists must learn from fishers, to understand how they view their system, in order to make the image-based tool useful in context. We then test its usefulness by exploring the hypothesis that the image-based framework can help fishers discuss with more depth and complexity because it provides a simple conceptual base for systems thinking and a core set of variables to consider as interacting. Furthermore, we explore how using the framework during deliberation may be able to alter the social-psychological outcomes of participants using field experimental methods. We discuss our combined methodology, for transforming the framework and measuring deliberation impacts, while reflecting on new ways of thinking about how the SESF can be useful for applied research and practice.
\end{abstract}

Key Words: collaboration; comanagement; environmental governance; facilitation; sustainability; transformation

\section{INTRODUCTION}

Finding more effective ways to communicate and exchange knowledge between science, policy, and practice is of significant interest for global environmental governance (Dietz et al. 2003, Cornell et al. 2013, McAllister and Taylor 2015). Rapid socialecological change requires urgent and well informed solutions (Steffen et al. 2015, Bodin 2017). However, difficulties with communication and exchanging different types of knowledge between diverse actors can hinder constructive decision making (Dietz 2013, Medin and Bang 2014). Solutions are not simple, and barriers are manifold. It is not always clear at which level, phase, or through which mechanisms different types of knowledge can best inform governance in meaningful and mutually accepted ways (Newig and Fritsch 2009, Raymond et al. 2010, Tengö et al. 2014). Similarly, it is not always clear when or how different actors can or should participate and bring their knowledge into governance processes (Reed 2008, Schneider and Buser 2018). The political nature of decision making, power asymmetries, or hierarchical actor relationships can create substantial barriers (Brechin et al. 2002, Underdal 2010).

As trends in environmental governance now shift toward more collaborative approaches (Roberts 2004, U.S. NRC 2008, Kenter et al. 2014, Bodin 2017) such as community-based comanagement, the focus of this study, the development of processes for communication and knowledge exchange are increasingly common (Berkes 2009). There are many definitions and variations of community-based comanagement, and more broadly collaborative governance, but all involve two core principles: (1) the participation of different actors (either within and/ or between groups) and (2) deliberation. Participation broadly refers to the processes by which the values and opinions of various stakeholder groups are incorporated into decisions of interest to the public at large (Fung and Wright 2001, U.S. NRC 2008). Participation and deliberative processes are social spaces for communicating ideas, collective action, creating or resolving conflicts, and for engaging in social learning (Stern 2005, Reed et al. 2010, Tengö et al. 2014). Deliberation involves reasoned dialogue to negotiate issues of mutual interest and to seek information. This includes learning from one another and consideration of evidence, other viewpoints, and values in dialogue, to provide decision support (Carpini et al. 2004, Carlsson and Berkes 2005, Kenter et al. 2014, Dryzek and Pickering 2017). Deliberation is a pillar for group decision making, and involves in-depth discussion toward a normative goal. However, while deliberation is essential for effective collaborative governance, it is not an inherently easy or simple process to facilitate.

Communication and knowledge exchange in community-based natural resource comanagement can face substantial barriers when actors attempt to work together who have different knowledge, past experiences, preferences, and understandings of a system, even within groups (Dietz 2013, Dryzek and Pickering 2017). Simply bringing people together is often not enough to generate constructive outcomes, a complex array of social and political processes can manifest (Crona and Hubacek 2010, Curșeu and Schruijer 2017). The institutional fit of communication and knowledge exchange processes within comanagement is critical so that ways of engaging with actors, the content being discussed, and solutions derived are contextually appropriate (Folke et al. 2007, Galaz et al. 2008, Cox 
2012, Epstein et al. 2015). Actors may face difficulties conveying their preferences, experiences, and knowledge about a system in a way that is understandable and useful to other actors, even to those within their group, e.g., fishers to fishers. For example, from a scientific perspective it is understood that environmental governance involves dealing with a complex system that has many social and ecological variables that interact to shape outcomes. However, scientists may face difficulties communicating with nonspecialists, and even other scientists, because of the esoteric nature of scientific terminology and concepts (Wong-Parodi and Strauss 2014). Similarly, actors may have knowledge or preferences on many aspects related to a system or governance, but hitting all the points and guiding deliberation in a way that accounts for all important aspects can be difficult (Castella et al. 2007). Facilitation is often needed to guide fruitful deliberation. Structured agendas or tools such as checklists, visual aids, and frameworks may be useful to help overcome barriers (Lynam et al. 2007, Rodríguez Estrada and Davis 2015).

Scientific frameworks serve numerous purposes for communication and knowledge exchange in academia, but they can also be useful for the same reasons in community-based comanagement settings, as we examine below. Frameworks often distill complex concepts or theories into core components or variables, typically in simple ways using key terminology and visual aids (Binder et al. 2013). In this article we specifically refer to and use Ostrom's social-ecological systems framework (SESF; Ostrom 2009, McGinnis and Ostrom 2014). The SESF conveys the complex concept of social-ecological systems (SES) in a simple way by illustrating how the core components of the system interact using a visual diagram (Fig. 1). The first-tier variables, or core components, include the Resource systems (RS), Resource units (RU), Governance systems (GS), and Actors (A). The SESF acts as a common language between academics. It also acts as a checklist to guide the analysis of complex systems, to help ensure that no important aspects are overlooked.

Fig. 1. The first-tier variables of the social-ecological systems (SES) framework (McGinnis and Ostrom, 2014).

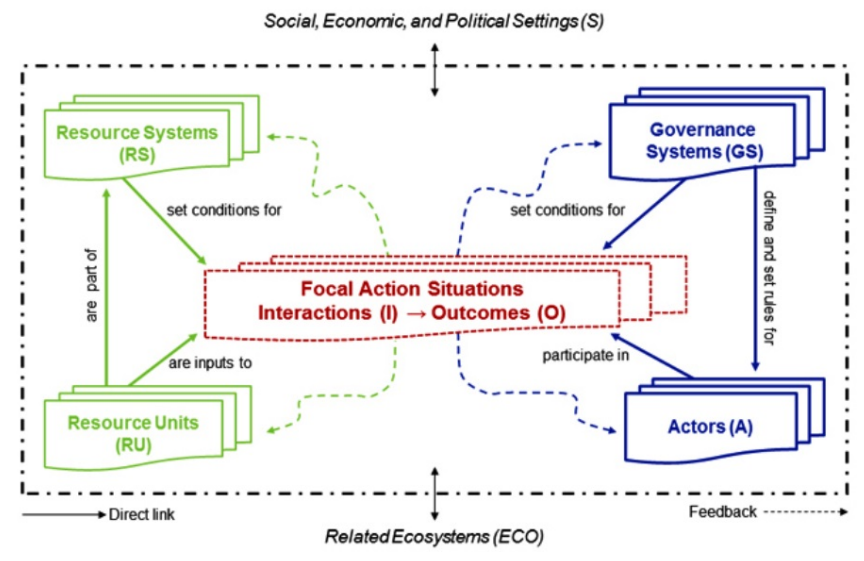

A scientific framework, like Ostrom's SESF, can serve similar functions as a knowledge exchange and deliberation tool in community-based comanagement settings. It can help convey systems thinking in a simple way and act as a checklist to ensure that all the core components of a complex system have the potential to be discussed and considered during deliberation and decision-making processes. From a scientific perspective, it is known that environmental governance deals with complex socialecological system interactions (Liu et al. 2007, Ostrom 2007, Bodin 2017). Having a tool that can communicate the basic tenets of systems thinking and prompt actors to bring in their own knowledge, beliefs, or preferences about the core components of a system may be useful for facilitating more in-depth and constructive dialogue.

However, there are still challenges for making a scientific framework, in this case the SESF, useful in practice. The SESF is not linked to a particular context and it uses noncontext specific and specialist terminology. Both aspects may hinder the ability of actors to associate the core concepts and components to a practical governance context. Complexity and the level of detail in a deliberative tool can also be a barrier to communication because scientists may tend to err on the side of precision and complexity (Knight et al. 2006, Sandker et al. 2010). To make the SESF a useful tool in practice, all aspects of the framework need to be understood by actors, i.e., nonspecialists, in a meaningful way. Developing methods to transform the framework for use by nonspecialists can potentially make the framework a more useful practical tool. Facilitation tools may be able to remove existing barriers for communication and knowledge exchange during deliberation. For science, developing facilitation tools can be viewed as a methodological challenge (Lynam et al. 2007). It has been suggested that enhanced deliberation processes may improve the achievement of community-based comanagement goals through better linking scientific analysis and the participation of other actors (Dietz 2013).

The purpose of this article is to rethink how the SESF can be useful as a practical tool for enhancing communication, knowledge exchange, and deliberation processes in communitybased natural resource comanagement. To do this, we have developed a methodology for transforming Ostrom's SESF (Ostrom 2009, McGinnis and Ostrom 2014) into images related to a specific governance context. We demonstrate this methodology by transforming the framework for use by smallscale fishers participating in fisheries comanagement in the Gulf of Nicoya, Costa Rica. We then demonstrate how to measure the usefulness of the transformed framework. We test its ability to facilitate dialogue with more depth and complexity (see methods section) as well as its impact on social-psychological metrics of actors using before-after control-impact (BACI) field experimental methods. Ultimately this article proposes a new way of using the SESF for applied research and practice, and demonstrates a methodology for testing if it may work. We explore numerous assumptions and hypotheses, which are shown in Table 1.

\section{Measuring experimental outcomes}

The effectiveness of a policy or the outcome of a treatment intervention can be measured in many ways; the specific metric frequently depends on the context, and expected and/ or desired outcome. However, equally important to all of them is the experimental (or quasi-experimental) control (Hurlbert 1984, Meyer 1995). Studies that compare subjects before and after a treatment risk the spurious influence of some unrecorded factor 
Table 1. Assumptions, hypotheses, and methods used in this study.

\begin{tabular}{ll}
\hline \hline Assumptions (A) and Hypothesis (H) & Methodology \\
\hline $\begin{array}{l}\text { A1: The social-ecological system framework (SESF) can be transformed into simple and context relevant } \\
\text { images, making it easier for nonacademics to understand and engage with. }\end{array}$ & See Table 2. \\
$\begin{array}{l}\text { H1: The image-based SESF can structure deliberative dialogue, i.e., helping to ensure that all important } \\
\text { aspects of a system have the opportunity to be discussed if necessary. }\end{array}$ & $\begin{array}{l}\text { Participatory observation of deliberative } \\
\text { dialogue } \\
\end{array}$ \\
$\begin{array}{ll}\text { H2: The image-based SESF facilitates deliberation with more depth and complexity, i.e., because it } \\
\text { provides a simple conceptual base for systems thinking as well as the core social and ecological variables in in } \\
\text { an accessible and nonacademic language. }\end{array}$ & $\begin{array}{l}\text { Participatory observation of deliberative } \\
\text { H3: The image-based SESF can enhance knowledge sharing, i.e., between actors by creating space for }\end{array}$ \\
$\begin{array}{l}\text { actors to share opinions by stimulating discussion. } \\
\text { H4: The image-based SESF, as a tool to structure discussions, can alter the mental models and social- } \\
\text { psychological metrics of actors. }\end{array}$ & Field experiment \\
\hline
\end{tabular}

that may happen to occur at the same time as the treatment. One such factor may be the researchers themselves, as the presence of an observer, e.g., a scientist, can change people's behavior (Franke and Kaul 1978). For example, social desirability bias may cause people to tell researchers what they want to hear (Nunnally 1967). A control theoretically helps to filter these effects because observer and social desirability effects are held constant between groups. Studies that compare control and treatment may be affected by other unobserved systematic differences between subjects, though this may be mitigated by random sampling and large sample sizes (Stewart-Oaten et al. 1986).

This group of analyses are called before-after control-impact (BACI) analysis (Green 1979, Stewart-Oaten et al. 1986) in the ecological literature, and is also known as the difference in differences (DD) model (Ashenfelter and Card 1985) commonly used in economics today. An illustration of this analysis can be seen in Figure 2, where a variable is measured before a treatment, and after. Individuals are randomly assigned to either a treatment or control group. Individual measurements may change over time unrelated to the treatment itself, but only the difference between these differences, i.e., the interaction between change over time and treatment $(\mathrm{BAxCI})$ is the treatment effect. In this illustration, if we only compared before-measurements to after-measurements in the treatment group, we may incorrectly assume that the entire increase observed was due to the treatment (in our case the use of the SESF as a deliberation tool). The control group shows a similar but slightly smaller increase over time; this is differenced out in the analysis.

\section{Measuring deliberative outcomes and hypothesis testing}

Any management process involves implicit normative criteria and goals, and efforts must be taken to treat these as explicitly and carefully as biophysical management and socioeconomic targets (Cooke et al. 2009, Fenichel et al. 2013). Participatory management and deliberation create venues to consider both normative and positive goals, but they also operate with broader implicit normative goals of, for example, increasing proenvironmental or prosocial outcomes (U.S. NRC 2008). As stated above, there are many context-specific methods to measure the outcomes of deliberative processes, i.e., measurement and item construction, but a very useful one involves environmental psychology, as it addresses implicit normative goals of deliberation, provides information useful to the deliberative and management process, and allows for hypothesis testing.
Fig. 2. Graphical representation of analyzing controlled experiments via before-after control-impact or difference in differences. SESF = social-ecological system framework.

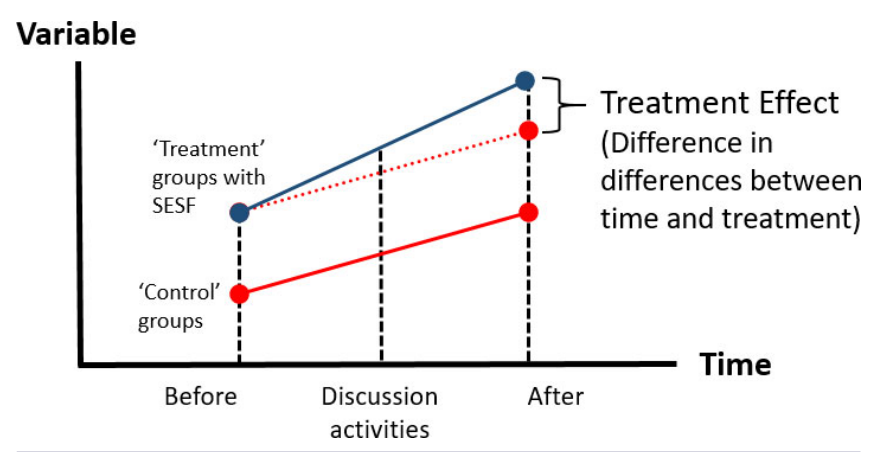

Environmental psychology is an important field that works to understand the motivations behind particular environmental behaviors, and evaluate how to change behaviors to be more proenvironmental (Stern 2000, Saunders et al. 2006). Environmental theories of behavior such as the theory of planned behavior (Ajzen 2005) or the cognitive hierarchy (Vaske and Donnelly 1999) help understand the psychological processes underlying decisions and assume a hierarchy of psychological constructs that exert influence on one another and ultimately inform behavior. For example, according to the theory of planned behavior, an intention to perform a specific proenvironmental behavior is related to performance of that behavior. That increases as the personal norm (i.e., feeling of obligation, of how one should behave), subjective norm (i.e., the perception of what others think one should do), attitude toward the behavior (i.e., a positive or negative evaluation of the behavior), and perceived behavioral control (i.e., the belief that the behavior is under one's volitional control) increases. The attitude toward a behavior is in turn influenced by one's mental models and beliefs about the consequences of behavior. These constructs have been shown to have great relevance in a variety of conservation contexts (Cooke et al. 2009, Decker et al. 2012, Milner-Gulland 2012), and are relevant to both managers and policy makers. Constructs both act as a baseline to understand what is acceptable and feasible, and as a relevant and useful way to measure the impact of participatory interventions (Fujitani et al. 2017). 
Psychometrics provides a way to measure psychological phenomena such as knowledge and mental models (e.g., fundamental beliefs), transcendental values, and contextual precursors of behavior (Klöckner 2013). Numerous psychometric constructs exist including knowledge sharing, mental models, and others connected with perceptions and performance of proenvironmental behaviors. These constructs can be statistically analyzed for hypothesis testing (Nunnally 1967). Further, many of the hypotheses associated with assumed effects of participation and deliberation are very appropriate for measurement using psychometric methods (Kenter et al. 2014, Fujitani et al. 2017). For example, a stated aim of deliberation is to discuss and develop contextual values, to shape and elicit social values, and iteratively update individual values (Kenter et al. 2014). Other important assumed outcomes of deliberation are knowledge sharing and an increase in feelings of empowerment (U.S. NRC 2008). Important aspects of all of these outcomes are covered by environmental theories of behavior, such as values in value belief norm theory (Stern 2000), fundamental beliefs in the cognitive hierarchy (Vaske and Donnelly 1999), and subjective norms, attitudes, and perceived behavioral control in the theory of planned behavior (Ajzen 2005).

\section{Small-scale fisheries and responsible fishing areas (AMPRs) in Costa Rica}

The Gulf of Nicoya is the largest tropical estuary in Central America, located on the Pacific Ocean coast of Costa Rica. The gulf supports more than 11,000 small-scale fishers. The Costa Rican Institute for Fisheries and Aquaculture (INCOPESCA) is supporting a small-scale fisheries management program to create responsible fishing areas (AMPRs) in line with the Food and Agriculture Organization of the United Nations (FAO) smallscale fisheries guidelines (FAO 2015). AMPRs have explicit goals to enhance ecological conservation by supporting communitybased comanagement with INCOPESCA to develop mutually accepted rules for fishing such as reducing harmful gear usage and overall effort. AMPRs also have the explicit goal to enhance conservation and social welfare by pursuing alternative livelihood opportunities not based on resource extraction such as aquaculture and tourism. Fishing communities that are willing and able to self-organize their own fishing association and develop a management plan can formally apply to get legal support from INCOPESCA. AMPRs have the exclusive rights to fish and enforce regulations within a spatially defined marine area (Lozano and Heinen 2016a, b). Both the process of creating the local fishing associations and interactions with INCOPESCA involve deliberation about rules and management strategies for the AMPR, which necessarily involves the inclusion of multiple groups of fishers using different gear types. Constructive deliberation and collective action for comanagement are necessary foundations for AMPR success. There are currently seven AMPRs in the Gulf of Nicoya. All fishers in this study live in communities with AMPRs, and have vested interest in its management (Fig. 3).

\section{METHODS}

Transforming the framework into images

A methodology for transforming the SESF into context relevant images is shown in Table 2, testing hypothesis 1 . Steps 1 through 6 , the transformation of the framework into images, were conducted in the community of Costa de Pajaros, an AMPR comanagement area in the Gulf of Nicoya. Step 7, the field experiment for measuring its effect on deliberation outlined in section 2.2, was conducted with fishers on Isla Chira and in Tambor, similar small-scale fishing comanagement areas with AMPRs in the Gulf of Nicoya. Starting with Step 1, exploratory semistructured and open ended interviews were conducted with small-scale fishers, local community leaders, nonfisher community members, and researchers from Costa Rican universities who focus on marine related issues. This step was guided by a general diagnostic approach using the SESF to build an understanding of which variables are most relevant for understanding the management of small-scale fisheries in the Gulf of Nicoya (Cox 2011, Hinkel et al. 2015, Partelow 2016).

Fig. 3. (A) Fishing association meeting at the Paquera-Tambor responsible fishing area (AMPR). (B) Trial deliberation and iterative feedback on the image-based framework with fishers and our research team in the Costa de Pajaros AMPR (Step 6 in Table 2). (C) Beach with small-scale fishing boats in Costa de Pajaros, a familiar setting throughout the Gulf of Nicoya. (D) Fishers deliberating in our field experiment.

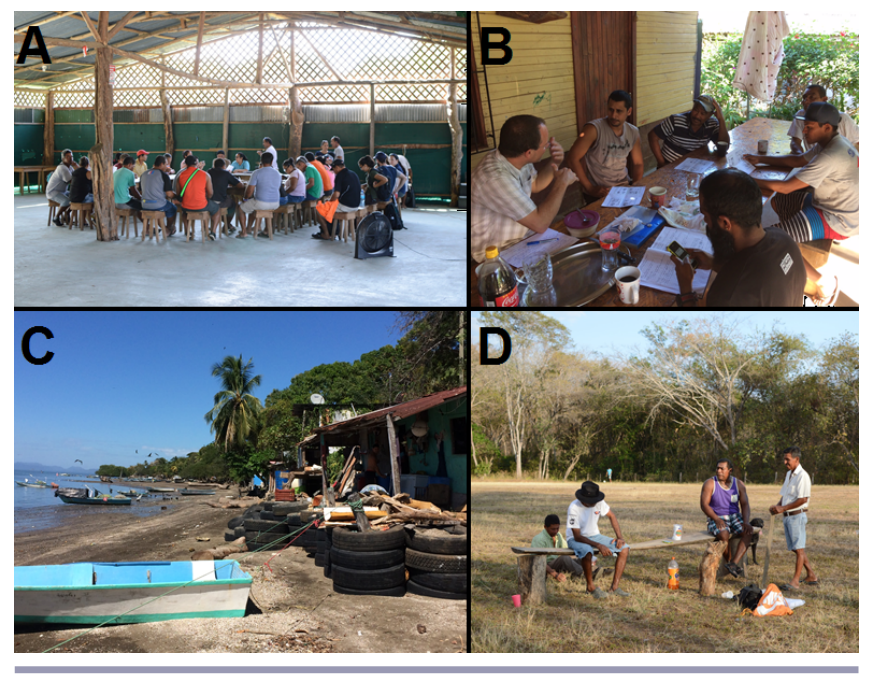

For Step 2, the relevant variables from the SESF were selected for transformation. We limited our scope to the first-tier variables. This was done for two reasons. Methodologically, this allowed us to use the second-tier variables as indicators for a content analysis (Stemler 2001) of deliberation transcripts. This was done to compare the depth (how much content in each first-tier variable of the SESF) and complexity (the evenness of content discussed between the first-tiers of the SESF) of deliberation transcripts between control and treatment groups. The second reason to limit images to the first-tier variables is for simplicity. Having images for each second-tier was thought to be too overwhelming and complex for our context. This would undermine the goal of having an approachable tool, while still emphasizing some of the tradeoffs between accuracy and complexity when working with stakeholders during participatory modeling (Knight et al. 2006, Castella et al. 2007).

Step 3 involved generating or finding images for each first-tier variable. Drawings and online searches generated usable open- 
Table 2. Methodological steps developing an image-based deliberation tool from a social-ecological system (SES) framework.

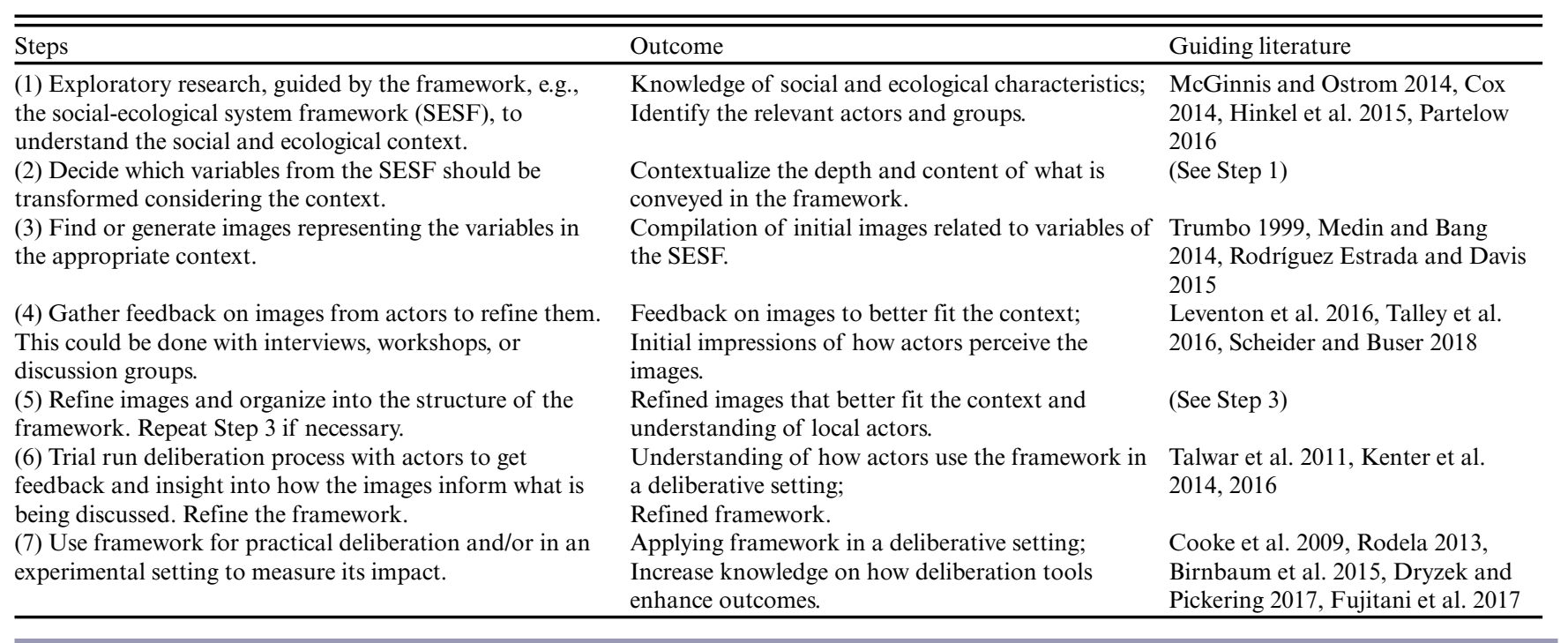

access images. In Step 4, all images were discussed again with fishers in Costa de Pajaros. We primarily asked two questions. First, we asked what they thought the images represented, and second, what images may better represent the first-tier variables based on their understanding of the system (i.e., for RS, RU, Gov, A). In Step 5, the feedback in Step 4 was used to refine and modify the images further. Steps 4 and 5 were done twice to get feedback and refine the images in two rounds. The final images were organized into the conceptual structure of the framework.

In Step 6, the final image-based version of the SESF was used in a trial deliberation process with a group of fishers (Fig. 3). We asked this group to discuss challenges facing small-scale fisheries in the Gulf of Nicoya and the management of their AMPR. The fishers discussed using the framework under passive observation by our research team. In the end, they were asked to provide feedback on whether the image-based framework was useful. Feedback was combined with our observations of the process. Minor adjustments were made to images and the presentation of the image-based framework for use in Step 7.

\section{Measuring deliberation impacts with field experiments}

Before-after control-impact field experiments were conducted to pilot test our hypotheses as a proof of concept. Groups of three to four fishers were gathered and asked to deliberate general challenges facing the management of fisheries for up to 30 minutes. Two control groups were asked to deliberate with no visual or information aids, just to discuss amongst themselves. Five treatment groups were given the transformed SESF, and were told they could use it as an aid for discussion. In this design, the treatment, or "impact," is the image-based SESF. Each group discussion was recorded with informed consent from the participants. Before and after each group discussion, each fisher completed a standardized questionnaire. This experimental design allowed control and treatment groups to be compared across measured domains before and after the deliberation activity.

\section{Measuring depth and complexity at the group level}

To test hypotheses 2 and 3, transcripts from the deliberation groups were translated into English and transcribed into the qualitative data analysis program MaxQDA. A content analysis (Stemler 2001) of each transcript was conducted using the secondtier variables of the SESF as a coding framework, as indicators to categorize discussion content (Table A1.1). Coding was consensus based, using a coding protocol developed by two authors. Transcripts were then first coded by one author, then again by a second author to check for intercoder reliability. After coding, the analysis involved the number of coded segments for each second-tier variable in each transcript. The sum total of second-tier variables within each first-tier, for each transcript, was used as a measure of discussion depth, i.e., the amount of content in each transcript related to each first-tier. The number of secondtier variables was averaged across the control and treatment groups separately for each first-tier variable (Table 3). The complexity of each discussion can be examined and compared in Table 3, i.e., the relative proportion or evenness of focus between first-tier variable content in the control and treatment groups.

\section{Measuring individual changes}

Elements from the theory of planned behavior (Ajzen 2005) and the cognitive hierarchy (Vaske and Manfredo 2012) were used to understand the behavioral intention to support the AMPR (Appendix 2) to assess hypothesis 5. This included the constructs of "perceived behavioral control toward the AMPR,"i.e., whether achieving the AMPR objectives are within their control; "attitude toward collective action for the AMPR," positive or negative assignment about collective action for the AMPR; "attitude toward regulatory authority with regards to the AMPR," i.e., whether they support and respect the regulations; and "personal and subjective norms toward the AMPR," i.e., whether they and the people they respect support the AMPR. We also evaluated the belief that the AMPR supports fishers. Items to measure beliefs, attitudes, and norms were constructed ad hoc based on qualitative preliminary work, as well as adapted from the 
Fig. 4. An image-based social-ecological system framework (SESF) transformed for use by fishers in the Gulf of Nicoya, Costa Rica. The image-based framework translates the general concept of systems thinking and social-ecological interactions through simple images and text.

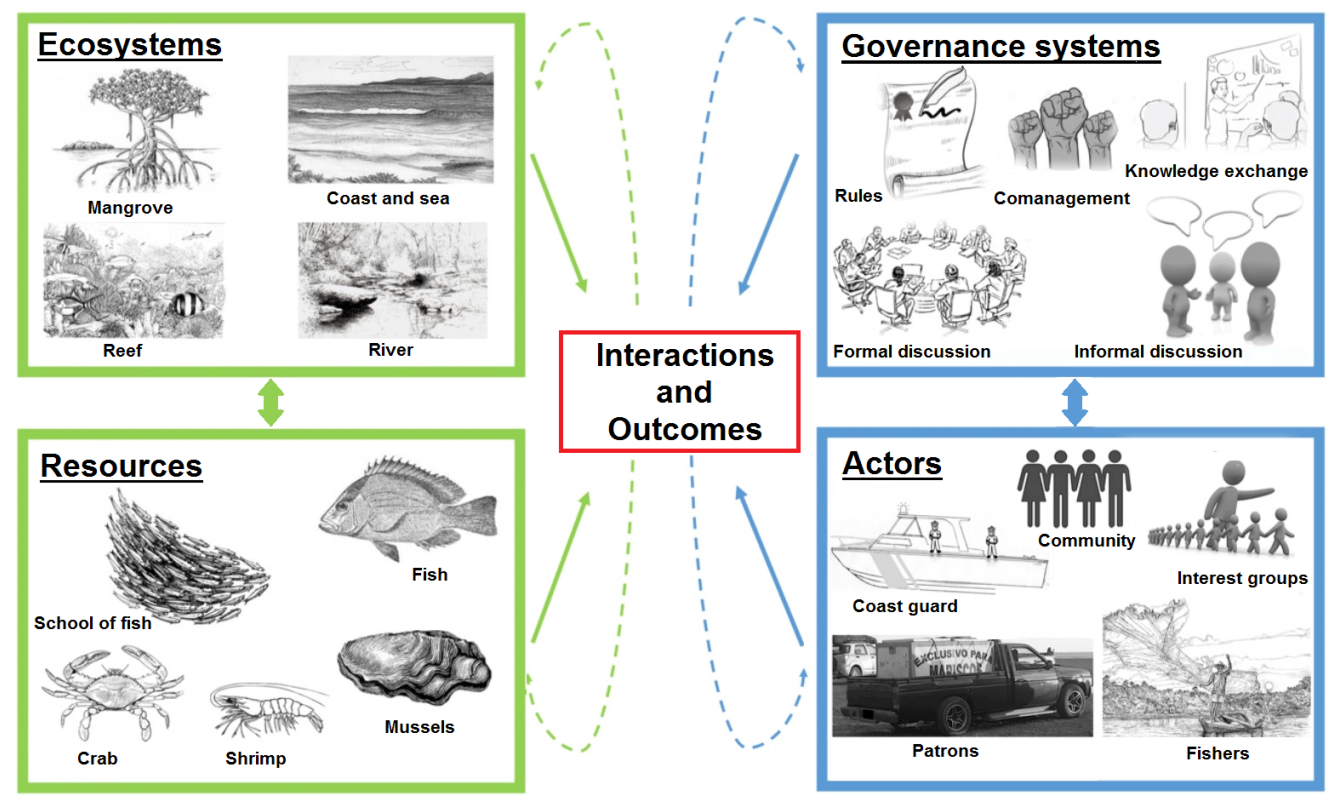

Table 3. Each deliberation transcript from the treatment and control groups was coded for content in relation to the socialecological system framework (SESF) second-tier variables. This table shows the mean number of coded segments from each group aggregated to each first-tier variable. The table allows comparison of the depth, i.e., amount of content within each first-tier, and complexity, i.e., the proportionality/evenness of content between first-tiers, of dialogue between the treatment and control groups.

\begin{tabular}{lcc}
\hline \hline SESF first-tier variables & $\begin{array}{c}\text { Average number } \\
\text { of coded } \\
\text { segments for } \\
\text { each variable in } \\
\text { the treatment } \\
\text { groups } \\
(\mathrm{N}=5)\end{array}$ & $\begin{array}{c}\text { Average number } \\
\text { of coded } \\
\text { segments for } \\
\text { each variable in } \\
\text { the control } \\
\text { groups } \\
(\mathrm{N}=2)\end{array}$ \\
\hline Social, economic, and political & 0 & 0 \\
settings (S) & 20.6 & 6 \\
Resource systems (RS) & 22.4 & 13.5 \\
Resource units (RU) & 58 & 40.5 \\
Actors (A) & 33.8 & 38 \\
Governance systems (GS) & 27.2 & 22 \\
Interactions (I) & 11.2 & 11.5 \\
Outcomes (O) & 0.2 & 0 \\
Related ecosystems (ECO) & \multicolumn{2}{|}{} \\
\hline
\end{tabular}

literature (Liebe et al. 2010, Allegretti et al. 2012, LópezMosquera and Sánchez 2012). The reliability of measures was checked by assessing internal consistency with Cronbach's alpha and by confirmatory factor analysis.

To evaluate hypotheses 2 and 3 from a different angle, we asked self-assessment questions to participants postactivity on the depth and complexity of the discussion (H2) as well as how the activity facilitated knowledge sharing $(\mathrm{H} 3)$ through discussion as well as aiding personal reflection (Appendix 3).

Constructs were obtained from mean Likert scales and analyzed with parametric methods. In the case where multi-item scales were not available, we applied the interval assumption to individual items with 5-point Likert response formats, as is a common practice because the interval assumption is conservative as it increases the likelihood of type II error ("false negative"; Bortz and Döring 2006). Treatment effects were assessed via linear mixed models (LMM) fit by restricted maximum likelihood in the statistical package R (http://cran.r-project.org), with the Likert scale construct as the dependent variable with dummy coefficients for fixed effects for the before (pretest) vs. the after (post-test), control vs. impact (SESF treatments), and the interaction between the two (BAxCI; the treatment effect), with individual nested within region random effects parsed from global variance. Where only the SESF treatment versus control measurements were available, i.e., control-impact postactivity assessments, the two groups were compared with Welch's t, given the unbalanced sample size and variance. Given randomization and large enough sample sizes, control-impact analyses can have advantages even over before-after control-impact analyses in terms of internal validity (Campbell and Stanley 1963).

\section{RESULTS}

Our image-based SESF is shown in Figure 4, transformed to the context of small-scale fishers in the Gulf of Nicoya, Costa Rica. The original conceptual structure of the SESF is retained and images are used to represent each first-tier variable, without reference to specific second-tier variables. In Resource systems and Resource units, images represent multiple co-occurring first- 
tiers. The Resource systems tier was labelled Ecosystems and shows four co-occurring first-tier systems: a mangrove forest, a reef, a riverine estuary, and a shoreline going out into the open sea. The Resource units tier was labelled Resources and shows a diversity of different species caught in the fishery. The Actors tier retained its label and shows different co-occurring first-tiers, i.e., groups of actors, including fishers, coast guard, the community, patrons, i.e., middlemen, and interest groups, e.g., NGOs. The Governance systems tier retained its name and shows the different governance systems including images related to rules, comanagement, knowledge exchange, formal and informal governance settings. The original version of the text in Figure 4 was generated in Spanish for use by local fishers, and was translated to English for this article. The development of the image-based SESF supports our assumption (A1) that it is possible to transform the framework into a contextualized imagebased tool for use by nonacademics. The process of transformation was accomplished by engaging local fishers through iterative learning, where we the researchers learned from fishers about how they view and understand their own system to generate the appropriate images. Below, the success of using the image-based SESF on deliberation processes is measured in two ways.

\section{Depth and complexity of deliberation at the group level}

The structure and content of discussions differed between treatment and control groups. Treatment groups used the imagebased SESF to loosely structure the content of discussion, often going through each of the four first-tier categories systematically. This supports our hypothesis (H1) that the SESF can provide structure to deliberation compared to the control. Treatment groups discussed with more depth, except on Governance systems because the control tended to discuss more exclusively content related to Governance systems. Treatment groups also discussed with more evenness than control groups. The control groups tended to start immediately discussing governance, monitoring, and compliance issues, thus discussing content related to the Governance systems tier in more depth than the treatment group. However, overall they discussed the other variables with less depth. The control groups (without the SESF) discussed with less complexity or evenness across variables (Table 3 ). These initial findings generally support our hypothesis (H2; Table 3$)$. The Social, economic, and political settings and External ecosystems first-tier variables were not included in our image-based framework, and no discussion content related to those variables. Variables from the Actors tier were the most frequently discussed in both groups, with a large portion of the content relating to the second-tier variable Knowledge of SES/ mental models, where fishers expressed their perceptions and opinions about issues of concern to the group.

\section{Impact of deliberation on individuals}

Understanding the baseline perceptions and attitudes toward the AMPR, as well as how this may change on account of deliberation (by applying a BACI framework) provides essential information for comanagement. Fishers across all sites indicated very positive personal norms and attitudes toward the AMPR, as well as beliefs that the AMPR was intended to benefit fishers. Perceived behavioral control toward achieving AMPR objectives was slightly lower. There was also more diversity among the regions with regard to the social norm of supporting the AMPR through observance of the regulations, and to lesser extent positive attitudes toward regulatory authority (Fig. 5). Participants in the discussion activities indicated overall agreement that the activity aided discussion complexity and depth, personal reflection about the topic, and facilitated knowledge exchange beyond what would occur without the activity (Fig. 5). Respondents deliberating with the aid of the visual SESF had a higher mean agreement than the control deliberators; however this difference is not statistically significant (Table 4).

Fig. 5. (A) Radar plot of baseline mean psychometric constructs for each of the four survey regions; scaled between 1 (more positive toward the responsible fishing area [AMPR] and regulatory authority) and 0 (See Appendix 1). (B) Radar plot of postdiscussion assessments by the participants of the activity; scaled between 1 (strong agreement) and 0 (strong disagreement; See Appendix 2). PBC AMPR = Perceived behavioral control toward the AMPR; P. Norm AMPR = Personal norm toward the AMPR.
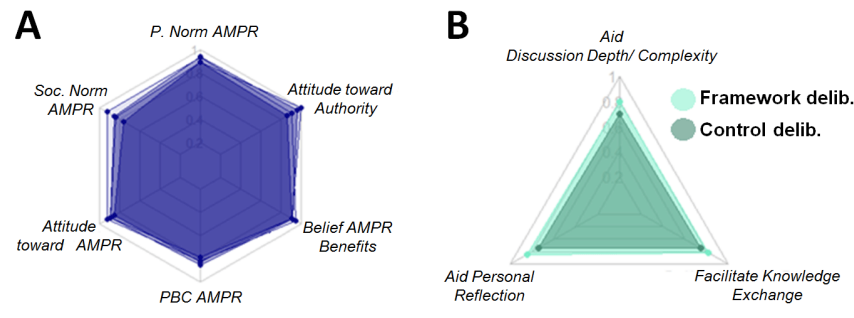

Given the limited and unbalanced sample size, it is unsurprising that measured constructs did not differ significantly between treatment and control groups (Tables 4 and 5). Post-hoc analyses show small to moderate effect sizes and very low statistical power (Tables 4 and 5). However, this work fulfills the goals of demonstrating proof of concept to guide future studies. We have evidence of good reliability in many of our constructs $(\alpha>0.7$; Nunnally 1967), and they can be used in similar contexts because no context-specific scales yet exist in the literature. In contrast, we would need to revisit our items measuring perceived behavioral control and attitude toward regulatory authority in this context. However, this study is a demonstration of an experimental design that would measure the constructs, e.g., norms, attitudes, perceived behavior control, relevant to an effective deliberative process for comanagement, and requires only a refinement with a larger randomly selected sample.

Though we did not find statistically significant differences between the treatment and control groups, it may be taken as an indication to further research, that, for example the differenced treatment group means were lower than the control group means (Table 5). As a thought experiment, this difference, if indicating the true treatment effect from a frequentist perspective, would indicate stronger agreement that the SESF discussion had more depth and complexity, aided personal reflection, and was useful to facilitate discussion, relative to the control. This information guides both future hypothesis development and future experimental planning, for example, as this provides empirical grounds to set a sample size. If the lack of significant treatment effects were due to a lack of statistical power to resolve these 
Table 4. Measured constructs.

\begin{tabular}{|c|c|c|c|c|c|c|c|c|}
\hline Construct & No. items & $\begin{array}{l}\text { Reliability } \\
(\alpha) \text { before }\end{array}$ & $\begin{array}{l}\text { Reliability }(\alpha) \\
\text { after }\end{array}$ & $\begin{array}{l}\text { Treatment } \\
\text { coefficient }^{\dagger}\end{array}$ & $\mathrm{SE}^{\dagger}$ & p-value ${ }^{\dagger}$ & $\begin{array}{c}\text { Effect size } \\
(\text { Cohen's d })^{\ddagger}\end{array}$ & Power $^{\ddagger}$ \\
\hline $\begin{array}{l}\text { Perceived behavioral control } \\
\text { toward the AMPR }\end{array}$ & 3 & 0.34 & 0.46 & 0.14 & 0.41 & 0.41 & 0.28 & 0.10 \\
\hline $\begin{array}{l}\text { Attitude toward collective } \\
\text { action for the AMPR }\end{array}$ & 3 & 0.66 & 0.83 & 0.16 & 0.40 & 0.69 & 0.15 & 0.06 \\
\hline $\begin{array}{l}\text { Personal norm toward the } \\
\text { AMPR }\end{array}$ & 3 & 0.83 & 0.77 & 0.00 & 0.18 & 0.99 & 0.04 & 0.05 \\
\hline $\begin{array}{l}\text { Subjective norm regarding } \\
\text { the AMPR }\end{array}$ & 1 & NA & NA & 0.01 & 0.39 & 0.98 & 0.06 & 0.05 \\
\hline $\begin{array}{l}\text { Belief the AMPR benefits } \\
\text { fishers }\end{array}$ & 5 & 0.83 & 0.8 & -0.18 & 0.25 & 0.47 & -0.29 & 0.11 \\
\hline $\begin{array}{l}\text { Attitude toward regulatory } \\
\text { authority }\end{array}$ & 4 & 0.5 & 0.54 & 0.19 & 0.29 & 0.52 & 0.37 & 0.14 \\
\hline
\end{tabular}

differences, we can use power analysis to calculate a necessary sample size given observed effect sizes and desired statistical power (Cohen 1988). Given the moderate effect sizes observed in the field experiment, a prudent sample size with sufficient power would range from 30 to 100 participants per treatment (Figure A1.1), in line with other workshop-based participation and deliberation studies (e.g., Lienhoop and MacMillan 2007, Carnoye and Lopes 2015).

\section{DISCUSSION}

Despite increased academic focus on community-based comanagement (Roberts 2004, U.S. NRC 2008, Kenter et al. 2014, Bodin 2017), making communication, knowledge exchange, and deliberation work in practice remains a substantial challenge (Newig and Fritsch 2009, Curșeu and Schruijer 2017). Communication and knowledge exchange is critical for progress (Cornell et al. 2013) because difficulties for working together are exacerbated when actors have different experiences, knowledge, beliefs, and understandings of a system (Bohensky and Maru 2011, Cornell et al. 2013). In this study we have approached these challenges as an opportunity to think outside-the-box and develop new applied research methods. In particular, we focus on the role of developing facilitation tools and testing their usefulness as interventions in community-based comanagement settings.

We have tried to rethink how an existing academic tool, the SESF (McGinnis and Ostrom 2014), can be used in new ways beyond its traditional applications (Partelow 2018). We show that the framework can be useful as a practical tool when transformed into a common language of images for nonspecialists, arguing that images can ground the framework into a relevant governance context for nonspecialists. The SESF can be a useful tool to convey systems thinking, social-ecological interactions, and a checklist of core system components through those images. In this sense, our study provides proof of concept to the idea that the usefulness of the SESF for scientists may be paralleled by its usefulness for practitioners.

Ultimately, the transformed image-based SESF explores one potential facilitation tool to make community-based comanagement more effective. However, new practical mechanisms and methodologies are needed to explore this idea further, and we have proposed numerous hypotheses to test how and why tools like the transformed SESF may be useful. We encourage further testing and critique of these hypotheses in more robust ways and in different contexts. There are a large variety of different types of community-based comanagement arrangements to explore (Berkes 2009), and each arrangement involving diverse actors likely warrants a contextualized approach. However, we argue that the processes for developing and implementing the image-based tool developed in this study may be generalizable in different contexts, e.g., beyond small-scale fisheries, because it allows images to be tailored to context through active engagement and codesigning with actors. However, we recognize that this needs further exploration and testing, which we encourage. Our study did not codesign the research with the actors; fishers only gave inputs to develop the image-based framework for deliberation, albeit in an iterative engagement process. This was done for reasons related to testing its usefulness as an intervention with experiments. However, in a practical setting, codesigning the framework with the actors who will use it may be beneficial and allow more participation and deliberation surrounding the process of development as well.

Furthermore, this study has demonstrated the idea of using an existing scientific tool, i.e., the SESF. However, many other socialecological systems frameworks exist (Binder et al. 2013) with similar core concepts such as ecosystem services (Partelow and Winkler 2016). There is potential to explore the role of using scientific frameworks in general, not just the SESF, to help communicate and exchange known scientific concepts related to environmental governance. For example, some core concepts are critical to consider when developing management policies such as social-ecological complexity and interactions as well as how those may occur at different levels and scales (Liu et al. 2007). There are numerous frameworks built on these core concepts (Binder et al. 2013). Subsequently, actors should be able to decide what to do with this knowledge once they have it, and the imagebased SESF may be able to transfer some of this knowledge in a passive way, without the active intercession of a scientist. There is a need to flatten perceived power or epistemic hierarchies that might be associated with having specialists actively involved in 
Table 5. Results between control and treatment.

\begin{tabular}{lccccccccc}
\hline \hline Variable & No. items & $\begin{array}{c}\text { Reliability } \\
(\alpha)\end{array}$ & $\begin{array}{c}\text { Mean } \\
\text { Control }\end{array}$ & $\begin{array}{c}\text { Mean } \\
\text { Treatment }\end{array}$ & Welch's t & p-value & SE (total) & Effect size & Power \\
\hline Aid to discussion depth & 2 & 0.77 & 1.95 & 1.64 & 0.91 & 0.38 & 0.75 & -0.41 & 0.17 \\
$\begin{array}{l}\text { and complexity } \\
\text { Aid to personal reflection }\end{array}$ & 3 & 0.80 & 1.80 & 1.50 & 1.08 & 0.30 & 0.59 & -0.51 & 0.24 \\
$\begin{array}{l}\text { Utility and facilitation of } \\
\text { exercise }\end{array}$ & 2 & 0.82 & 1.80 & 1.58 & 0.75 & 0.47 & 0.61 & -0.36 & 0.24 \\
\hline
\end{tabular}

deliberative settings (Fung and Wright 2001, Klenk et al. 2015). For example, the presence of a perceived expert or the frontal presentation-style transfer of knowledge has been shown to hinder the engagement or contributions of nonspecialists (Lord 1999, Voinov and Gaddis 2008). However, many formal comanagement arrangements have formal settings, for example on a deliberation council (e.g., Santos and Schiavetti 2014, Partelow et al. 2018) or management committee (e.g., Partelow and Boda 2015), where scientists are necessarily one of the actors involved. In other cases, scientists may be involved in a consulting capacity, or not formally involved at all, such as in the Gulf of Nicoya case study examined here. The use of facilitation tools to enhance knowledge sharing between actors in different types of comanagement arrangements and cultural contexts would be a useful direction for future research. Nonetheless, there will inevitably be power asymmetries between different groups of actors, and facilitation tools that are transparent and collaborative in design may help flatten those that may have negative consequences to ensure more equitable participation through providing a mechanism for intervention (U.S. NRC 2008).

It is necessary that knowledge exchange and communication is multidirectional, and not just a one-way transfer of scientific knowledge to other actors. Numerous studies have shown that this can increase the perceived legitimacy and acceptability of governance processes, ultimately leading to the development of more effective management, rules, and compliance (Berkes 2009, Van Tatenhove 2013, Tengö et al. 2014, Bennett 2016). We argue that the usefulness of the SESF is not limited to conveying scientific knowledge to other actors. It is equally important to improve communication and the exchange of knowledge between actors, e.g., between fishers, through social learning. Social learning is a critical process for human development and cooperation (Reed et al. 2010, Cundill and Rodela 2012, Dietz 2013). It can help build trust and mitigate conflict between actors if it can be well facilitated in deliberative settings (Berkes 2009). However, there are many layers and complexities associated with social learning processes (Reed et al. 2010), and one important aspect is the role of actor perceptions in governance processes (Bennett 2016, Beyerl et al. 2016). If the perceptions actors have of other actors, and of the governance process, are that they are legitimate and acceptable, it is likely that they will participate, communicate, and exchange knowledge in more constructive ways, leading to better outcomes for both people and nature (Bennett 2016).

Although this study conducts an applied research project, it is evident that there is considerable potential to use a transformed
SESF in a practical setting and we encourage exploring practical uses in future work. Critical questions remain about what influences constructive actor participation and deliberation, what influences communication and knowledge exchange, and about how to design research that can help test potential tools for supporting these processes. For example, this study focuses on actors within a single group (only fishers), and further research could examine between-group knowledge exchange, i.e., between fishers and other actors such as government officials. Further research could also explore tailoring the framework for use in more formal management and deliberative settings with multiple groups of diverse actors involved. There are many methodological approaches that may be useful for exploring these questions, some of which are demonstrated above. Measuring and testing changes in environmental psychology, mental models, and prosocial behavior are promising inquiries. These are integral dimensions for understanding how individual changes lead to collective behavioral phenomena or manifest into decision making for resource use and governance (Saunders et al. 2006, Swim et al. 2009, Fujitani et al. 2017). Field experimental methods and the BACI method are useful for parsing out differences in treatment effects, and we have demonstrated how to do this in our study. There is also room to explore these methods with larger and more balanced sample sizes, but also with additional methods such as participatory workshops and qualitative research to examine social-psychological changes in individuals and groups in greater depth.

Social science field experiments can be challenging because they involve organizing the participation of many individuals who have to volunteer time, even if compensated. Recruitment of participant fishers proved to be a substantial challenge in this study for a variety of reasons including the willingness and ability of fishers to commit to a future time and date to meet, the willingness to engage with us as outsiders, and a lack of interest in discussing the issues of interest to the study. This was our own shortcoming because we did not succeed in building the trust/ social capital needed in each community or to establish the proper incentives for fishers to participate to the extent necessary that would have provided a more substantial sample size. Building trust, particularly with community leaders, is critical for ensuring participation, as well as respecting the mental models of actors, e.g., how they think about and organize their time, and ensuring that there is a reasonable incentive and culturally appropriate conditions for them to participate. For transforming the SESF into images (Step 1 to 6), we established a good relationship with the AMPR community leader in Costa de Pajaros, who helped recruit other fishers to participate. In Isla Chira and Tambor, where the field experiments were conducted, establishing a 
relationship with the community leaders was more difficult, with more challenges for recruiting participant fishers. Sampling participants was largely done by approaching groups of fishers opportunistically, without preplanning the deliberation activity. However, even with random assignment, bias can persist, for example, the choice to participate is often nonrandom (Heckman 1992). Thus, the challenges and careful introspection on the extent of inferential validity experienced in this pilot study are relevant to all field undertakings.

In a final reflection, the importance of the social and ecological settings and dynamics in which the community-based comanagement occurs is high (Fujitani et al. 2018). This is captured by the literature on institutional fit (Folke et al. 2007, Galaz et al. 2008, Cox 2012, Epstein et al. 2015). Consideration of how different types of deliberative and knowledge exchange processes fit within the type of comanagement arrangement, and thus within the broader social-ecological settings, is important. This brings in the larger issue of framing in deliberative processes. Whether the actors participating are conscious of it or not, the framing of a deliberative process and the perceived legitimacy of that content plays a substantial role in altering outcomes. If we only deliberate governance issues or biological targets, our focus is likely to remain within those boundaries, even if the problem is broader and better solved with a more holistic framing (Fujitani et al. 2018). If we deliberate linked social-ecological system issues, perhaps we will find solutions that more appropriately fit the broader systems context. The image-based SESF may create space for systems thinking, reframing what is deliberated.

\section{CONCLUSIONS}

Shifts toward community-based comanagement are promising, but in order to ensure that such arrangements lead to beneficial outcomes for both people and nature, they require the participation of different actors and constructive deliberation between them. Communication and knowledge exchange are critical to this process, and facilitation tools can support deliberative processes in different ways that lead to more effective achievement of desired outcomes, both collectively and at the individual level. This study has demonstrated how the socialecological systems framework (SESF) can be transformed into an image-based facilitation tool that can help actors discuss with more depth and complexity. The transformed framework can convey basic scientific knowledge that is generally important for governance such as systems thinking and social-ecological complexity in a passive and simple way. The SESF may also help knowledge exchange and communication among actors. We believe this study has shown a proof of concept for the ideas and hypotheses outlined above, and we encourage future studies to explore them further.

Responses to this article can be read online at: http://www.ecologyandsociety.org/issues/responses. php/10724

\section{Acknowledgments:}

We acknowledge funding from the Leibniz Centre for Tropical Marine Research (ZMT) to conduct this research and publish this article open-access. We also extend our deep gratitude to the individuals and communities who allowed us to engage with them and conduct this research in Costa Rica. We are grateful to the editors and anonymous reviewers for their detailed and constructive comments.

\section{LITERATURE CITED}

Ajzen, I. 2005. Attitudes, personality and behavior. Second edition. Open University Press, Maidenhead, UK.

Allegretti, A. M., J. J. Vaske, and R. Finchum. 2012. Conflict and normative sanctions among Galapagos fishermen. Pages 91-97 in C. L. Fisher and C. E. Watts Jr, editors. Proceedings of the 2010 Northeastern Recreation Research Symposium. General Technical Report NRS-P-94. U.S. Forest Service, Northern Research Station, Newtown Square, Pennsylvania, USA.

Ashenfelter, O., and D. Card. 1985. Using the longitudinal structure of earnings to estimate the effect of training programs. Review of Economics and Statistics 67:648-660. http://dx.doi. org/10.2307/1924810

Ashenfelter, O., and D. Card. 1985. Using the longitudinal structure of earnings to estimate the effect of training programs. Review of Economics and Statistics 67:648-660. http://dx.doi. org/10.2307/1924810

Bennett, N. J. 2016. Using perceptions as evidence to improve conservation and environmental management. Conservation Biology 30(3):582-592. http://dx.doi.org/10.1111/cobi.12681

Berkes, F. 2009. Evolution of co-management: role of knowledge generation, bridging organizations and social learning. Journal of Environmental Management 90(5):1692-1702. http://dx.doi. org/10.1016/j.jenvman.2008.12.001

Beyerl, K., O. Putz, and A. Breckwoldt. 2016. The role of perceptions for community-based marine resource management. Frontiers in Marine Science 3(238). http://dx.doi.org/10.3389/ fmars.2016.00238

Binder, C. R., J. Hinkel, P. W. G. Bots, and C. Pahl-Wostl. 2013. Comparison of frameworks for analyzing social-ecological systems. Ecology and Society 18(4):26. http://dx.doi.org/10.5751/ ES-05551-180426

Birnbaum, S., Ö. Bodin, and A. Sandström. 2015. Tracing the sources of legitimacy: the impact of deliberation in participatory natural resource management. Policy Sciences 48(4):443-461. https://doi.org/10.1007/s11077-015-9230-0

Bodin, Ö. 2017. Collaborative environmental governance: achieving collective action in social-ecological systems. Science 357(6352):eaan1114. http://dx.doi.org/10.1126/science.aan1114

Bohensky, E. L., and Y. Maru. 2011. Indigenous knowledge, science, and resilience: What have we learned from a decade of international literature on "integration"? Ecology and Society 16 (4):6. http://dx.doi.org/10.5751/ES-04342-160406

Bortz, J., and N. Döring. 2006. Forschungsmethoden und Evaluation. Springer, Berlin, Germany. http://dx.doi. org/10.1007/978-3-540-33306-7

Brechin, S. R., P. R. Wilshusen, C. L. Fortwang, and P. C. West. 2002. Beyond the square wheel: toward a more comprehensive 
understanding of biodiversity conservation as a social and political process. Society and Natural Resources 15:41-64. http:// dx.doi.org/10.1080/089419202317174011

Campbell, D. T., and J. C. Stanley. 1963. Experimental and quasiexperimental designs for research. Houghton Mifflin, Boston, Massachusetts, USA.

Carlsson, L., and F. Berkes. 2005. Co-management: concepts and methodological implications. Journal of Environmental Management 75(1):65-76. http://dx.doi.org/10.1016/j.jenvman.2004.11.008

Carnoye, L., and R. Lopes. 2015. Participatory environmental valuation: a comparative analysis of four case studies. Sustainability 7:9823-9845. http://dx.doi.org/10.3390/su7089823

Carpini, M. X. D., F. L. Cook, and L. R. Jacobs. 2004. Public deliberation, discursive participation, and citizen engagement: a review of the empirical literature. Annual Review of Political Science 7:315-344. http://dx.doi.org/10.1146/annurev. polisci.7.121003.091630

Castella, J.-C., S. P. Kam, D. D. Quang, P. H. Verburg, and C. T. Hoanh. 2007. Combining top-down and bottom-up modelling approaches of land use/cover change to support public policies: application to sustainable management of natural resources in northern Vietnam. Land Use Policy 24:531-545. http://dx.doi. org/10.1016/j.landusepol.2005.09.009

Cohen, J. 1988. Statistical power analysis for the behavioral sciences. Erlbaum Associates, Hillsdale, New Jersey, USA. http:// dx.doi.org/10.4324/9780203771587

Cooke, I. R., S. A. Queenborough, E. H. A. Mattison, A. P. Bailey, D. L. Sandars, A. R. Graves, J. Morris, P. W. Atkinson, P. Trawick, R. P. Freckleton, A. R. Watkinson, and W. J. Sutherland. 2009. Integrating socio-economics and ecology: a taxonomy of quantitative methods and a review of their use in agro-ecology. Journal of Applied Ecology 46:269-277. http://dx.doi.org/10.1111/ j.1365-2664.2009.01615.x

Cornell, S., F. Berkhout, W. Tuinstra, J. D. Tàbara, J. Jäger, I. Chabay, B. de Wit, R. Langlais, D. Mills, P. Moll, I. M. Otto, A. Petersen, C. Pohl, and L. van Kerkhoff. 2013. Opening up knowledge systems for better responses to global environmental change. Environmental Science and Policy 28:60-70. http://dx.doi. org/10.1016/j.envsci.2012.11.008

Cox, M. 2011. Advancing the diagnostic analysis of environmental problems. International Journal of the Commons 5 (2):346-363. http://dx.doi.org/10.18352/ijc. 273

Cox, M. 2012. Diagnosing institutional fit: a formal perspective. Ecology and Society 17(4):54. http://dx.doi.org/10.5751/ ES-05173-170454

Cox, M. 2014. Applying a social-ecological system framework to the study of the Taos Valley Irrigation System. Human Ecology 42(2):311-324. http://dx.doi.org/10.1007/s10745-014-9651-y

Crona, B., and K. Hubacek. 2010. The right connections: How do social networks lubricate the machinery of natural resource governance? Ecology and Society 15(4):18. http://dx.doi. org/10.5751/ES-03731-150418

Cundill, G., and R. Rodela. 2012. A review of assertions about the processes and outcomes of social learning in natural resource management. Journal of Environmental Management 113:7-14. http://dx.doi.org/10.1016/j.jenvman.2012.08.021

Curșeu, P. L., and S. G. Schruijer. 2017. Stakeholder diversity and the comprehensiveness of sustainability decisions: the role of collaboration and conflict. Current Opinion in Environmental Sustainability 28:114-120. http://dx.doi.org/10.1016/j.cosust.2017.09.007

Decker, D. J., S. J. Riley, and W. F. Siemer. 2012. Human dimensions of wildlife management. Johns Hopkins University Press, Baltimore, Maryland, USA.

Dietz, T. 2013. Bringing values and deliberation to science communication. Proceedings of the National Academy of Sciences 110(Supplement 3):14081-14087. http://dx.doi.org/10.1073/ pnas. 1212740110

Dietz, T., E. Ostrom, and P. C. Stern. 2003. The struggle to govern the commons. Science 302(5652):1907-1912. http://dx.doi. org/10.1126/science.1091015

Dryzek, J. S., and J. Pickering. 2017. Deliberation as a catalyst for reflexive environmental governance. Ecological Economics 131:353-360. http://dx.doi.org/10.1016/j.ecolecon.2016.09.011

Epstein, G., J. Pittman, S. M. Alexander, S. Berdej, T. Dyck, U. Kreitmair, K. J. Raithwell, S. Villamayor-Tomas, J. Vogt, and D. Armitage. 2015. Institutional fit and the sustainability of socialecological systems. Current Opinion in Environmental Sustainability 14:34-40. http://dx.doi.org/10.1016/j.cosust.2015.03.005

Fenichel, E. P., B. Gentner, and R. Arlinghaus. 2013. Normative considerations for recreational fishery management: a bioeconomic framework for linking positive science and normative fisheries policy decisions. Fisheries Management and Ecology 20(2-3):223-233. http://dx.doi.org/10.1111/j.1365-2400.2012.00869. $\underline{\mathrm{X}}$

Folke, C., L. Pritchard, F. Berkes, J. Colding, and U. Svedin. 2007. The problem of fit between ecosystems and institutions: ten years later. Ecology and Society 12(1):30. http://dx.doi.org/10.5751/ ES-02064-120130

Food and Agriculture Organization of the United Nations (FAO). 2015. Voluntary guidelines for securing sustainable small-scale fisheries in the context of food security and poverty eradication. FAO, Rome, Italy.

Franke, R. H., and J. D. Kaul. 1978. The Hawthorne experiments: first statistical interpretation. American Sociological Review 43:623-643. http://dx.doi.org/10.2307/2094540

Fujitani, M. L., E. P. Fenichel, J. Torre, and L. R. Gerber. 2018. Synthesizing ecological and human use information to understand and manage coastal change. Ocean and Coastal Management 162:100-109. http://dx.doi.org/10.1016/j. ocecoaman.2017.10.001

Fujitani, M., A. McFall, C. Randler, and R. Arlinghaus. 2017. Participatory adaptive management leads to environmental learning outcomes extending beyond the sphere of science. Science Advances 3(e1602516):1-11. http://dx.doi.org/10.1126/ $\underline{\text { sciadv. } 1602516}$

Fung, A., and E. O. Wright. 2001. Deepening democracy: innovations in empowered participatory governance. Politics and Society 29(1):5-41. http://dx.doi.org/10.1177/0032329201029001002 
Galaz, V., P. Olsson, T. Hahn, C. Folke, and U. Svedin. 2008. The problem of fit among biophysical systems, environmental and resource regimes, and broader governance systems: insights and emerging challenges. Pages 147-186 in O. R. Young, L. A. King, and $\mathrm{H}$. Schroede, editors. Institutions and environmental change: principal findings, applications, and research frontiers. MIT Press, Cambridge, Massachusetts, USA. http://dx.doi.org/10.7551/ mitpress/9780262240574.003.0005

Green, R. H. 1979. Sampling design and statistical methods for environmental biologists. Wiley, Chichester, UK.

Heckman, J. 1992. Randomization and social policy evaluation. Pages 201-230 in C. Manski and I. Garfinkle, editors. Evaluations: welfare and training programs. Harvard University Press, Cambridge, Massachusetts, USA.

Hinkel, J., M. E. Cox, M. Schlüter, C. R. Binder, and T. Falk. 2015. A diagnostic procedure for applying the social-ecological systems framework in diverse cases. Ecology and Society 20(1):32. http://dx.doi.org/10.5751/ES-07023-200132

Hurlbert, S. H. 1984. Pseudoreplication and the design of ecological field experiments. Ecological Monographs 54 (2):187-211. http://dx.doi.org/10.2307/1942661

Kenter, J. O., R. Bryce, M. Christie, N. Cooper, N. Hockley, K. N. Irvine, I. Fazey, L. O'Brien, J. Orchard-Webb, N. Ravenscroft, C. M. Raymond, M. S. Reed, P. Tett, and V. Watson. 2016. Shared values and deliberative valuation: future directions. Ecosystem Services 21:358-371. http://dx.doi.org/10.1016/j.ecoser.2016.10.006

Kenter, J. O., M. S. Reed, M. Everard, K. N. Irvine, E. O'Brien, C. Molloy, R. Bryce, E. Brady, M. Christie, A. Church, et al. 2014. Shared, plural and cultural values: a handbook for decision-makers, in UK National Ecosystem Assessment follow-on phase. UN Environment Programme World Conservation Monitoring Centre, Cambridge, UK.

Klenk, N. L., K. Meehan, S. L. Pinel, F. Mendez, P. T. Lima, and D. M. Kammen. 2015. Stakeholders in climate science: beyond lip service? Science 350:743-744. http://dx.doi.org/10.1126/ science.aab1495

Klöckner, C. A. 2013. A comprehensive model of the psychology of environmental behaviour: a meta-analysis. Global Environmental Change 23:1028-1038. http://dx.doi.org/10.1016/j. gloenvcha.2013.05.014

Knight, A. T., A. Driver, R. M. Cowling, K. Maze, P. G. Desmet, A. T. Lombard, M. Rouget, M. A. Botha, A. F. Boshoff, J. G. Castley, P. S. Goodman, K. Mackinnon, S. M. Pierce, R. SimsCastley, W. I. Stewart, and A. Von Hase. 2006. Designing systematic conservation assessments that promote effective implementation: best practice from South Africa. Conservation Biology 20:739-750. http://dx.doi.org/10.1111/j.1523-1739.2006.00452. $\underline{\mathrm{x}}$

Leventon, J., L. Fleskens, H. Claringbould, G. Schwilch, and R. Hessel. 2016. An applied methodology for stakeholder identification in transdisciplinary research. Sustainability Science 11(5):763-775. http://dx.doi.org/10.1007/s11625-016-0385-1

Liebe, U., P. Preisendörfer, and J. Meyerhoff. 2010. To pay or not to pay: competing theories to explain individuals' willingness to pay for public environmental goods. Environment and Behavior (43):106-130. http://dx.doi.org/10.1177/0013916509346229

Lienhoop, N., and D. C. MacMillan. 2007. Contingent valuation: comparing participant performance in group-based approaches and personal interviews. Environmental Values 16:209-232. http:// dx.doi.org/10.3197/096327107780474500

Liu, J., T. Dietz, S. R. Carpenter, M. Alberti, C. Folke, E. Moran, A. N. Pell, P. Deadman, T. Kratz, J. Lubchenco, E. Ostrom, Z. Ouyang, W. Provencher, C. L. Redman, S. H. Schneider, and W. W. Taylor. 2007. Complexity of coupled human and natural systems. Science 317(5844):1513-1516. http://dx.doi.org/10.1126/ science. 1144004

López-Mosquera, N., and M. Sánchez. 2012. Theory of planned behavior and the value-belief-norm theory explaining willingness to pay for a suburban park. Journal of Environmental Management (113):251-262. http://dx.doi.org/10.1016/j.jenvman.2012.08.029

Lord, T. R. 1999. A comparison between traditional and constructivist teaching in environmental science. Journal of Environmental Education 30:22-27. http://dx.doi. org/10.1080/00958969909601874

Lozano, A. J. G., and J. T. Heinen. 2016a. Identifying drivers of collective action for the co-management of coastal marine fisheries in the Gulf of Nicoya, Costa Rica. Environmental Management 57:759-769. http://dx.doi.org/10.1007/s00267-015-0646-2

Lozano, A. J. G., and J. T. Heinen. 2016b. Property relations and the co-management of small-scale fisheries in Costa Rica: lessons from marine areas for responsible fishing in the Gulf of Nicoya. Marine Policy 73:196-203. http://dx.doi.org/10.1016/j.marpol.2016.08.011

Lynam, T., W. De Jong, D. Sheil, T. Kusumanto, and K. Evans. 2007. A review of tools for incorporating community knowledge, preferences, and values into decision making in natural resources management. Ecology and Society 12(1):5. http://dx.doi. org/10.5751/ES-01987-120105

McAllister, R. R. J., and B. M. Taylor. 2015. Partnerships for sustainability governance: a synthesis of key themes. Current Opinion in Environmental Sustainability 12:86-90. http://dx.doi. org/10.1016/i.cosust.2015.01.001

McGinnis, M. D., and E. Ostrom. 2014. Social-ecological system framework: initial changes and continuing challenges. Ecology and Society 19(2):30. http://dx.doi.org/10.5751/ES-06387-190230

Medin, D. L., and M. Bang. 2014. The cultural side of science communication. Proceedings of the National Academy of Sciences 111(Supplement 4):13621-13626. http://dx.doi.org/10.1073/ pnas. 1317510111

Meyer, B. D. 1995. Natural and quasi-experiments in economics. Journal of Business and Economic Statistics 13:151-161.

Milner-Gulland, E. J. 2012. Interactions between human behaviour and ecological systems. Philosophical Transactions of the Royal Society B: Biological Sciences 367:270-278. http://dx. doi.org/10.1098/rstb.2011.0175

Newig, J., and O. Fritsch. 2009. Environmental governance: participatory, multi-level - and effective? Environmental Policy and Governance 19(3):197-214. http://dx.doi.org/10.1002/eet.509 
Nunnally, J. C. 1967. Psychometric theory. McGraw-Hill, New York, New York, USA.

Ostrom, E. 2007. A diagnostic approach for going beyond panaceas. Proceedings of the National Academy of Sciences of the United States of America 104(39):15181-15187. http://dx.doi. org/10.1073/pnas.0702288104

Ostrom, E. 2009. A general framework for analyzing sustainability of social-ecological systems. Science 325 (5939):419-422. http://dx.doi.org/10.1126/science.1172133

Partelow, S. 2016. Coevolving Ostrom's social-ecological systems (SES) framework and sustainability science: four key co-benefits. Sustainability Science 11(3):399-410. http://dx.doi.org/10.1007/ $\underline{\text { s11625-015-0351-3 }}$

Partelow, S. 2018. A review of the social-ecological systems framework: applications, methods, modifications, and challenges. Ecology and Society 23(4):36. http://dx.doi.org/10.5751/ ES-10594-230436

Partelow, S., and C. Boda. 2015. A modified diagnostic socialecological system framework for lobster fisheries: case implementation and sustainability assessment in southern California. Ocean and Coastal Management 114:204-217. http:// dx.doi.org/10.1016/j.ocecoaman.2015.06.022

Partelow, S., M. Glaser, S. Solano Arce, R. Sá Leitão Barboza, and A. Schlüter. 2018. Mangroves, fishers, and the struggle for adaptive comanagement: applying the social-ecological systems framework to a marine extractive reserve (RESEX) in Brazil. Ecology and Society 23(3):19. http://dx.doi.org/10.5751/ ES-10269-230319

Partelow, S., and K. J. Winkler. 2016. Interlinking ecosystem services and Ostrom's framework through orientation in sustainability research. Ecology and Society 21(3):27. http://dx. doi.org/10.5751/ES-08524-210327

Raymond, C. M., I. Fazey, M. S. Reed, L. C. Stringer, G. M. Robinson, and A. C. Evely. 2010. Integrating local and scientific knowledge for environmental management. Journal of Environmental Management 91(8):1766-1777. http://dx.doi. org/10.1016/j.jenvman.2010.03.023

Reed, M. S. 2008. Stakeholder participation for environmental management: a literature review. Biological Conservation 141 (10):2417-2431. http://dx.doi.org/10.1016/j.biocon.2008.07.014

Reed, M. S., A. Evely, G. Cundill, I. Fazey, J. Glass, A. Laing, J. Newig, B. Parrish, C. Prell, C. Raymond, and L. Stringer. 2010. What is social learning? Ecology and Society 15(4):r1. http://dx. doi.org/10.5751/ES-03564-1504r01

Roberts, N. 2004. Public deliberation in an age of direct citizen participation. American Review of Public Administration 4 (4):315-353. http://dx.doi.org/10.1177/0275074004269288

Rodela, R. 2013. The social learning discourse: trends, themes and interdisciplinary influences in current research. Environmental Science and Policy 25:157-166. http://dx.doi.org/10.1016/j. envsci.2012.09.002

Rodríguez Estrada, F. C., and L. S. Davis. 2015. Improving visual communication of science through the incorporation of graphic design theories and practices into science communication. Science Communication 37(1):140-148. http://dx.doi.org/10.1177/10755$\underline{47014562914}$

Sandker, M., B. M. Campbell, M. Ruiz-Pérez, J. A. Sayer, R. Cowling, H. Kassa, and A. T. Knight. 2010. The role of participatory modeling in landscape approaches to reconcile conservation and development. Ecology and Society 15(2):13. http://dx.doi.org/10.5751/ES-03400-150213

Santos, C. Z., and A. Schiavetti. 2014. Assessment of the management in Brazilian Marine Extractive Reserves. Ocean and Coastal Management 93:26-36. http://dx.doi.org/10.1016/j. ocecoaman.2014.03.007

Saunders, C. D., A. T. Brook, and O. E. Myers Jr. 2006. Using psychology to save biodiversity and human well-being. Conservation Biology 20:702-705. http://dx.doi.org/10.1111/ j.1523-1739.2006.00435.X

Schneider, F., and T. Buser. 2018. Promising degrees of stakeholder interaction in research for sustainable development. Sustainability Science 13:129-142. http://dx.doi.org/10.1007/ s11625-017-0507-4

Steffen, W., W. Broadgate, L. Deutsch, O. Gaffney, and C. Ludwig. 2015. The trajectory of the Anthropocene: The Great Acceleration. Anthropocene Review 2:81-98. http://dx.doi. org/10.1177/2053019614564785

Stemler, S. 2001. An overview of content analysis. Practical Assessment, Research \& Evaluation 7(17).

Stern, P. C. 2000. Psychology and the science of humanenvironment interactions. American Psychologist 55:523-530. http://dx.doi.org/10.1037/0003-066X.55.5.523

Stern, P. C. 2005. Deliberative methods for understanding environmental systems. BioScience 55(11):976-982. http://dx.doi. org/10.1641/0006-3568(2005)055[0976:DMFUES]2.0.CO;2

Stewart-Oaten, A., W. W. Murdoch, and K. R. Parker. 1986. Environmental impact assessment: "pseudoreplication" in time? Ecology 67:929-940. http://dx.doi.org/10.2307/1939815

Swim, J., S. Clayton, T. Doherty, R. Gifford, G. Howard, J. Reser, P. Stern, and E. Weber. 2009. Psychology and global climate change: addressing a multi-faceted phenomenon and set of challenges. American Psychological Association, Washington, D. C., USA.

Talley, J. L., J. Schneider, and E. Lindquist. 2016. A simplified approach to stakeholder engagement in natural resource management: the Five-Feature Framework. Ecology and Society 21(4):38. http://dx.doi.org/10.5751/ES-08830-210438

Talwar, S., A. Wiek, and J. Robinson. 2011. User engagement in sustainability research. Science and Public Policy 38(5):379-390. http://dx.doi.org/10.3152/030234211X12960315267615

Tengö, M., E. S. Brondizio, T. Elmqvist, P. Malmer, and M. Spierenburg. 2014. Connecting diverse knowledge systems for enhanced ecosystem governance: the multiple evidence base approach. Ambio 43(5):579-591. http://dx.doi.org/10.1007/ $\underline{\mathrm{s} 13280-014-0501-3}$ 
Trumbo, J. 1999. Visual literacy and science communication. Science Communication 20(4):409-425. http://dx.doi. org/10.1177/1075547099020004004

Underdal, A. 2010. Complexity and challenges of long-term environmental governance. Global Environmental Change 20 (3):386-393. http://dx.doi.org/10.1016/j.gloenvcha.2010.02.005

U.S. National Research Council(NRC). 2008. Public participation in environmental assessment and decision making. National Academies Press, Washington, D.C., USA.

Van Tatenhove, J. P. M. 2013. How to turn the tide: developing legitimate marine governance arrangements at the level of the regional seas. Ocean and Coastal Management 71:296-304. http:// dx.doi.org/10.1016/j.ocecoaman.2012.11.004

Vaske, J. J., and M. P. Donnelly. 1999. A value-attitude-behavior model predicting wildland preservation voting intentions. Society and Natural Resources 12:523-537. http://dx.doi.

org/10.1080/089419299279425

Vaske, J. J., and M. J. Manfredo. 2012. Social psychological considerations in wildlife management. Pages 43-57 in D. J. Decker, S. J. Riley, and W. F. Siemer, editors. Human dimensions of wildlife management. Johns Hopkins University Press, Baltimore, Maryland, USA.

Voinov, A., and E. J. B. Gaddis. 2008. Lessons for successful participatory watershed modeling: a perspective from modeling practitioners. Ecological Modelling 216:197-207. http://dx.doi. org/10.1016/j.ecolmodel.2008.03.010

Wong-Parodi, G., and B. H. Strauss. 2014. Team science for science communication. Proceedings of the National Academy of Sciences 111:13658-13663. http://dx.doi.org/10.1073/pnas.1320021111 


\section{Appendix 1}

Table A1.1 Indicators used, and their corresponding SESF variables, to measure the content of deliberation transcripts.

\begin{tabular}{|c|c|c|c|}
\hline SESF 1st tier & $\begin{array}{l}\text { General criteria for } \\
\text { qualitative coding }\end{array}$ & $\begin{array}{l}\text { SESF } 2^{\text {nd }} \text { tier } \\
\text { (content variables) }\end{array}$ & $\begin{array}{l}\text { Indicator terms and (concepts) } \\
\text { used to represent variables }\end{array}$ \\
\hline $\begin{array}{l}\text { Resource } \\
\text { systems (RS) }\end{array}$ & $\begin{array}{l}\text { Content relating to } \\
\text { coastal or marine } \\
\text { ecosystems and } \\
\text { ecological processes }\end{array}$ & $\begin{array}{l}\text { RS1 - Sector } \\
\text { RS2 - Clarity of system boundaries } \\
\text { RS3 - Size of resource system } \\
\text { RS4 - Human-constructed facilities } \\
\text { RS5 - Productivity of system } \\
\text { RS6 - Equilibrium properties } \\
\text { RS7 - Predictability of system dynamics } \\
\text { RS8 - Storage characteristics } \\
\text { RS9 - Location }\end{array}$ & $\begin{array}{l}\text { Mangroves, river, ecosystem, } \\
\text { reproduction (of general system), } \\
\text { habitat, fishing area, coral reef, } \\
\text { rock reef, coast, nature, natural } \\
\text { system, resource system, bay, } \\
\text { tides, health (of system) }\end{array}$ \\
\hline $\begin{array}{l}\text { Resource } \\
\text { units (RU) }\end{array}$ & $\begin{array}{l}\text { Content relating to } \\
\text { specific harvestable } \\
\text { species }\end{array}$ & $\begin{array}{l}\text { RU1 - Resource unit mobility } \\
\text { RU2 - Growth or replacement rate } \\
\text { RU3 - Interaction among resource units } \\
\text { RU4 - Economic value } \\
\text { RU5 - Number of units } \\
\text { RU6 - Distinctive characteristics } \\
\text { RU7 - Spatial and temporal distribution }\end{array}$ & $\begin{array}{l}\text { Fish, amounts of fish, sea bass, } \\
\text { snapper, lobster, oyster, value of } \\
\text { fish, reproduction (specific } \\
\text { species), seaweed, shrimp, species } \\
\text { locations, species behavior }\end{array}$ \\
\hline Actors (A) & $\begin{array}{l}\text { Content relating to } \\
\text { specific people, actor } \\
\text { groups and /or social } \\
\text { conditions }\end{array}$ & $\begin{array}{l}\text { A1 - Number of relevant actors } \\
\text { A2 - Socioeconomic attributes } \\
\text { A3 - History or past experiences } \\
\text { A4 - Location } \\
\text { A5 - Leadership/entrepreneurship } \\
\text { A6 - Norms /social capital } \\
\text { A7 - Knowledge of SES/mental models } \\
\text { A8 - Importance of resource } \\
\text { A9 - Technologies available }\end{array}$ & $\begin{array}{l}\text { Fishers, (reference to specific } \\
\text { individuals), patrons, markets, } \\
\text { income, gear used, (perceptions), } \\
\text { (past events), (reference to } \\
\text { community), gender, leadership, } \\
\text { (beliefs), communication }\end{array}$ \\
\hline $\begin{array}{l}\text { Governance } \\
\text { systems (GS) }\end{array}$ & $\begin{array}{l}\text { Content related to } \\
\text { management, } \\
\text { governance or } \\
\text { organizations } \\
\text { involved }\end{array}$ & $\begin{array}{l}\text { GS1 - Government organizations } \\
\text { GS2 - Nongovernment organizations } \\
\text { GS3 - Network structure } \\
\text { GS4 - Property-rights systems } \\
\text { GS5 - Operational-choice rules } \\
\text { GS6 - Collective-choice rules } \\
\text { GS7 - Constitutional-choice rules } \\
\text { GS8 - Monitoring and sanctioning rules }\end{array}$ & $\begin{array}{l}\text { Coast Guard, INCOPESCA, CNP, } \\
\text { management, governance, } \\
\text { (reference to specific rules), } \\
\text { regulations, enforcement, fines, } \\
\text { institutions, surveillance, } \\
\text { associations, organizations }\end{array}$ \\
\hline $\begin{array}{l}\text { Interactions } \\
\text { (I) }\end{array}$ & $\begin{array}{l}\text { Content relating } \\
\text { specific interactions } \\
\text { in social organization, } \\
\text { or people and nature. }\end{array}$ & $\begin{array}{l}\text { I1- Harvesting } \\
\text { I2- Information sharing } \\
\text { I3- Deliberation processes } \\
\text { 14- Conflicts } \\
\text { I5- Investment activities } \\
\text { I6- Lobbying activities } \\
\text { 17- Self-organizing activities } \\
\text { I8- Networking activities } \\
\text { 19- Monitoring activities } \\
\text { I10- Evaluative activities }\end{array}$ & $\begin{array}{l}\text { Harvesting, (aspects related } \\
\text { directly to catching fish), } \\
\text { information, (aspects related to } \\
\text { sharing information between } \\
\text { participants), (aspects related to } \\
\text { conflict situations), investment, } \\
\text { (aspects related to investments of } \\
\text { time or money), (aspects related to } \\
\text { self-organization), (aspects related } \\
\text { to evaluating the performance of } \\
\text { management) }\end{array}$ \\
\hline $\begin{array}{l}\text { Outcomes } \\
\text { (0) }\end{array}$ & $\begin{array}{l}\text { Content relating to } \\
\text { perceived outcomes }\end{array}$ & $\begin{array}{l}\text { O1 - Social performance measures } \\
\text { O2 - Ecological performance measures } \\
\text { O3 - Externalities to other SESs }\end{array}$ & $\begin{array}{l}\text { Benefits, bad, future, impacts, } \\
\text { (aspects related to perceptions of } \\
\text { social outcomes), (aspects related } \\
\text { to perceptions of ecological } \\
\text { outcomes) }\end{array}$ \\
\hline
\end{tabular}


Figure A1.1 Plot of necessary sample sizes given desired statistical power, over a range of observed effect sizes from the field experiment (Cohen's d), at significance level 0.05.

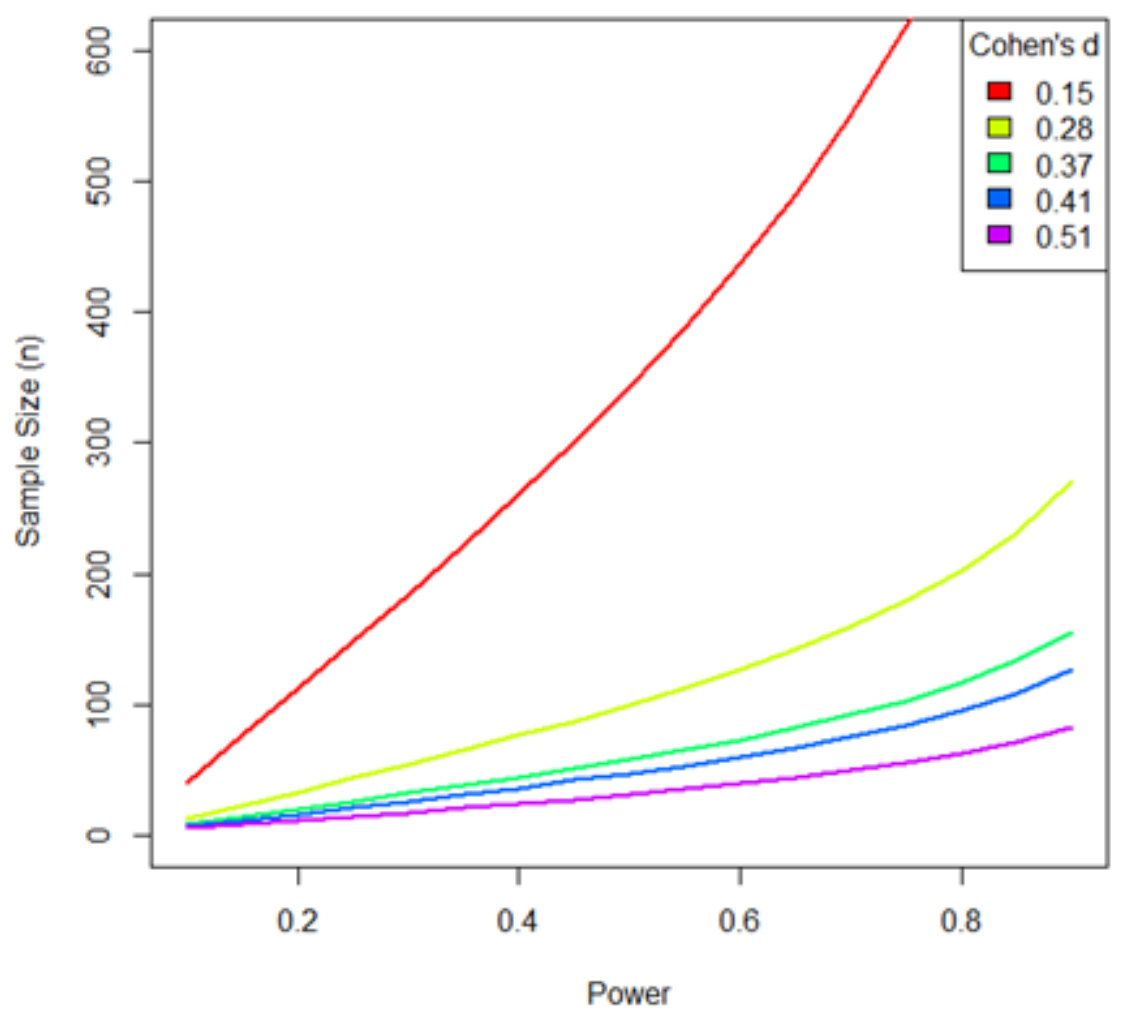


Table A2.1 Constructs, items and response format used to understand the behavioral intention to support the AMPR.

\begin{tabular}{|c|c|c|}
\hline Construct & Items & Response format \\
\hline \multirow[t]{3}{*}{$\begin{array}{l}\text { Perceived } \\
\text { behavioral } \\
\text { control } \\
\text { towards the } \\
\text { AMPR }\end{array}$} & $\begin{array}{l}\text { Discussing with other fishermen will not change their } \\
\text { compliance with the regulations of the AMPR (reverse) }\end{array}$ & \multirow{13}{*}{$\begin{array}{l}\text { Strongly agree }-1 \text {, } \\
\text { Agree-2, } \\
\text { Neutral/neither agree } \\
\text { nor disagree-3, } \\
\text { Disagree- } 4 \text {, Strongly } \\
\text { disagree-5 }\end{array}$} \\
\hline & It is difficult to achieve the objectives of the AMPR (reverse) & \\
\hline & $\begin{array}{l}\text { It is possible for the AMPR to achieve its objectives with all the } \\
\text { fishers involved }\end{array}$ & \\
\hline \multirow{3}{*}{$\begin{array}{l}\text { Attitude } \\
\text { towards } \\
\text { collective } \\
\text { action for the } \\
\text { AMPR }\end{array}$} & $\begin{array}{l}\text { It is important that communities and community members work } \\
\text { together to achieve the objectives of the AMPR }\end{array}$ & \\
\hline & $\begin{array}{l}\text { It is important to have discussions like this with other people } \\
\text { who were not part of this exercise }\end{array}$ & \\
\hline & $\begin{array}{l}\text { It is important to have discussions like this one with fishers who } \\
\text { have different perspectives on AMPR }\end{array}$ & \\
\hline \multirow{3}{*}{$\begin{array}{l}\text { Personal } \\
\text { norm } \\
\text { towards the } \\
\text { AMPR }\end{array}$} & I feel a personal obligation to follow the rules of the AMPR & \\
\hline & $\begin{array}{l}\text { I feel a personal obligation to act to achieve the objectives of } \\
\text { the AMPR }\end{array}$ & \\
\hline & $\begin{array}{l}\text { I feel a personal obligation to work together with other fishers } \\
\text { and members of the community to achieve the objectives of the } \\
\text { AMPR. }\end{array}$ & \\
\hline $\begin{array}{l}\text { Subjective } \\
\text { norm } \\
\text { regarding the } \\
\text { AMPR }\end{array}$ & The people I respect will follow the rules of the AMPR & \\
\hline \multirow{3}{*}{$\begin{array}{l}\text { Belief the } \\
\text { AMPR } \\
\text { benefits } \\
\text { fishers }\end{array}$} & The main objective of the AMPR is to benefit fishermen & \\
\hline & $\begin{array}{l}\text { The objective of the AMPR is to protect mainly fish and } \\
\text { shellfish }\end{array}$ & \\
\hline & $\begin{array}{l}\text { The AMPR is administered both for the protection of resources } \\
\text { and for their use }\end{array}$ & \\
\hline
\end{tabular}




\begin{tabular}{|c|c|c|}
\hline & $\begin{array}{l}\text { The resources of the AMPR are very important for fishers to } \\
\text { earn a living }\end{array}$ & \\
\hline & $\begin{array}{l}\text { The use of the AMPR and its resources must be sustainable } \\
\text { (not diminish for future generations) }\end{array}$ & \\
\hline \multirow{4}{*}{$\begin{array}{l}\text { Attitude } \\
\text { towards } \\
\text { regulatory } \\
\text { authority }\end{array}$} & $\begin{array}{l}\text { The authorities decide to extend the closure based on scientific } \\
\text { information }\end{array}$ & \multirow{4}{*}{$\begin{array}{l}\text { Strongly agree with } \\
\text { the decision-1, } \\
\text { Discreetly disagree- } \\
\text { 2, Express } \\
\text { disagreements-3, } \\
\text { Strongly protest the } \\
\text { decision-4, Not } \\
\text { comply with the } \\
\text { decision-5 }\end{array}$} \\
\hline & The authorities decide to expand the AMPR area & \\
\hline & The collection center decides to establish a daily catch per kg & \\
\hline & $\begin{array}{l}\text { The authorities prohibit the use of gillnets throughout the Gulf of } \\
\text { Nicoya }\end{array}$ & \\
\hline
\end{tabular}


Table A3.1 Outcomes, items and response format used for the self-assessment questions given to participants post activity.

\begin{tabular}{|c|c|c|}
\hline $\begin{array}{l}\text { Self-reported outcomes from } \\
\text { discussion }\end{array}$ & Items & Response format \\
\hline \multirow[t]{2}{*}{$\begin{array}{l}\text { Aid to discussion depth and } \\
\text { complexity }\end{array}$} & $\begin{array}{l}\text { This exercise helped me to discuss more complex and } \\
\text { profound issues about the AMPR }\end{array}$ & \multirow{7}{*}{$\begin{array}{l}\text { Strongly agree -1, } \\
\text { Agree-2, } \\
\text { Neutral/neither } \\
\text { agree nor disagree-3, } \\
\text { Disagree-4, Strongly } \\
\text { disagree-5 }\end{array}$} \\
\hline & $\begin{array}{l}\text { The process helped to raise issues in discussion that } \\
\text { would not have arisen in a normal conversation } \\
\text { environment }\end{array}$ & \\
\hline \multirow[t]{3}{*}{ Aid to personal reflection } & $\begin{array}{l}\text { This process helped me to better understand the } \\
\text { challenges in the AMPR }\end{array}$ & \\
\hline & $\begin{array}{l}\text { This exercise helped me to understand better the } \\
\text { importance of management (control and regulation of } \\
\text { gears) in the AMPR }\end{array}$ & \\
\hline & $\begin{array}{l}\text { This exercise helped me think about the importance of } \\
\text { many aspects of the AMPR }\end{array}$ & \\
\hline \multirow[t]{2}{*}{$\begin{array}{l}\text { Usefulness to facilitate } \\
\text { knowledge exchange }\end{array}$} & $\begin{array}{l}\text { The group exercise was useful to understand the } \\
\text { perspectives of other fishers }\end{array}$ & \\
\hline & This exercise helped to facilitate this discussion group & \\
\hline
\end{tabular}

